\title{
First-time Isolation of Flavonoids and Cytotoxic Potential of the Amazonian Shrub Ptychopetalum olacoides Benth
}

\author{
Dutra, K. D. B.; Macedo, A. L.; Montenegro, R. C.; Jimenez, P. C.; Castro, \\ R. N.; Epifanio, R. A.;† Vasconcelos, T. R. A.; Valverde, A. L.*
}

Rev. Virtual Quim., 2017, 9 (6), 2299-2304. Data de publicação na Web: 4 de dezembro de 2017

http://rvq.sbq.org.br

\section{Primeiro Isolamento de Flavonoides e Potencial Citotóxico do Arbusto Amazônico Ptychopetalum olacoides Benth}

Resumo: No presente estudo, três flavonoides, 3-O-metilquercetina (1), 3,4'-Odimetilquercetina (2) e 3,7-O-dimetilquercetina (3), foram isolados e caracterizados pela primeira vez a partir do extrato metanólico da espécie Ptychopetalum olacoides Benth. As estruturas das substâncias foram elucidadas por métodos espectroscópicos (1D-, 2D-RMN, EM e UV) e confirmadas por comparação com a literatura. A atividade citotóxica do extrato bruto foi avaliada in vitro contra três linhagens de células humanas cancerígenas. Foi observada atividade moderada $\left(\mathrm{Cl}_{50}=45.16 \mu \mathrm{g} / \mathrm{mL}\right)$ contra a linhagem de câncer de mama (MCF-7) e, além disso, o extrato bruto não foi citotóxico contra a linhagem de fibroblastos humanos não cancerígenos (MRC-5).

Palavras-chave: Antitumoral; câncer; flavonoides; Olacaceae; P. olacoides.

\begin{abstract}
In the present study, three flavonoids, 3-O-methylquercetin (1), 3,4'-O-dimethylquercetin (2) and 3,7-O-dimethylquercetin (3) were isolated and characterized for the first time from a methanol extract obtained from the species Ptychopetalum olacoides. The structures of compounds were identified by spectroscopic methods (1D-, 2D-NMR, MS and UV) and confirmed by comparison with the respective literature data. The cytotoxic effect of crude extract was evaluated in vitro against three human cancer cell lines. The results showed a mild cytotoxic activity $\left(\mathrm{IC}_{50}=45.16 \mu \mathrm{g} / \mathrm{mL}\right.$ ) against breast cancer (MCF-7). However, crude extract did not exhibit any cytotoxic effect against normal cell human fibroblast (MRC-5).
\end{abstract}

Keywords: Antitumor; cancer; flavonoids; Olacaceae; P. olacoides.

\footnotetext{
* Universidade Federal Fluminense, Instituto de Química, Departamento de Química Orgânica, Campus do Valonguinho, 24020-141, Niterói-RJ, Brazil.

\# Shared first author position.

+ in memoriam

Malessandravalverde@id.uff.br

DOI: $10.21577 / 1984-6835.20170137$
} 


\title{
First-time Isolation of Flavonoids and Cytotoxic Potential of the Amazonian Shrub Ptychopetalum olacoides Benth
}

\author{
Karen D. B. Dutra, ${ }^{\text {a,\# }}$ Arthur L. Macedo, ${ }^{\mathrm{a}, \#}$ Raquel C. Montenegro, ${ }^{\mathrm{b}}$ Paula
} C. Jimenez, ${ }^{\mathrm{c}}$ Rosane N. Castro, ${ }^{\mathrm{d}}$ Rosângela de A. Epifanio, ${ }^{\mathrm{a}}{ }^{+}$Thatyana R. A. Vasconcelos, ${ }^{a}$ Alessandra L. Valverde ${ }^{\mathrm{a}, *}$

a Universidade Federal Fluminense, Instituto de Química, Departamento de Química Orgânica, Campus do Valonguinho, CEP 24020-141, Niterói-RJ, Brazil.

b Universidade Federal do Pará, Instituto de Ciências Biológicas, CEP 66075-110, Belém-PA, Brazil.

' Universidade Federal de São Paulo, Departamento de Ciências do Mar, CEP 11070-100, Santos-SP, Brazil.

dUniversidade Federal Rural do Rio de Janeiro, Departamento de Química, CEP 23897-000, Seropédica-RJ, Brazil.

* alessandravalverde@id.uff.br

Recebido em 23 de março de 2017. Aceito para publicação em 27 de novembro de 2017

1. Introduction

2. Materials and methods

2.1. General procedures

2.2. Plant material

2.3. Extraction and isolation

2.4. Identification

2.5. Cytotoxic activity assay

\section{Results and discussion}

4. Conclusion

\section{Introduction}

Ptychopetalum olacoides Benth. (Olacaceae) is a shrub or small tree widely known in Brazil as "muirapuama", "marapuama", "marapuana" and "muiratã". ${ }^{1}$ This is an endemic species to the Amazon rainforest and specially distributed in the north region of the country in Amazonas, Amapá and Pará states. ${ }^{2}$ Preparations with the stems of $P$. olacoides have been used to treat "nervous weakness", fatigue, depression symptoms, tremor disorders, and sexual dysfunction. ${ }^{3}$ The fluid root extract of this plant has been employed in phytotherapeutic formulations as Catuama ${ }^{\circledR}$, a general tonic widely used in some regions 
of Brazil. ${ }^{4}$ However, there are few data related to the phytochemical profile of this species. Montrucchio and co-workers previously reported the isolation of saturated fatty acids (stearic and palmitic acids), methylxanthine caffeine, triterpenoid lupeol and steroid $\beta$-sitosterol. ${ }^{5}$ Other studies described the isolation of clerodane diterpenoids, ${ }^{6}$ benzoic acid derivatives such as vanillic and protocatechuic acids, and methylxanthine theobromine. ${ }^{7}$ Despite validation of the total flavonoids content from $P$. olacoides, ${ }^{8}$ there are no reports concerning isolation and characterization of flavonoids in this genus.

\section{Materials and methods}

\subsection{General procedures}

TLC was performed on plates pre-coated with silica gel $60 \mathrm{~F}_{254}$ (Merck, Germany). Preparative HPLC was performed on a Phenomenex $\mathrm{C} 18(30 \mathrm{~cm} \times 10 \mathrm{~mm} \times 5 \mu \mathrm{m}$, Torrance, Canada) equipped with a Shimadzu LC-10AS pump and a SPD10A UV/Vis detector (Shimadzu, Kyoto, Japan). The UV spectra were recorded on a JASCO V-370 Bio spectrophotometer (Tokyo, Japan). The NMR spectra were measured on Varian VNMRS $500 \mathrm{MHz}$ spectrometer for ${ }^{1} \mathrm{H}$ and $125 \mathrm{MHz}$ for ${ }^{13} \mathrm{C}$ (Palo Alto, USA), and chemical shifts were reported in ppm downfield from TMS. The MS data were recorded on a Flexar SQ 300 LC/MS system (PerkinElmer, Shelton, CT, USA) using an analytical C18 column (PerkinElmer, $150 \mathrm{~mm} \times 4.6 \mathrm{~mm}, 3 \mu \mathrm{m}$ ). A micro-splitter valve was used to send $45 \%$ of the flow to the mass spectrometer. The quadrupole mass spectrometer equipped with electrospray ionization(ESI-MS) was operated under positive ion mode. The MS parameters were set at $12 \mathrm{~L} / \mathrm{min}$ for drying gas flow, 80 psi for nebulizer pressure and $300{ }^{\circ} \mathrm{C}$ for drying gas temperature. Column chromatography was carried out on Sephadex LH-20.

\subsection{Plant material}

The powdered wood/bark of $P$. olacoides was acquired from Santosflora Herbs Ltda. (CNPJ: $\quad 51569309 / 0001-38, \quad$ IBAMA registration No. 35867 and ANVISA's authorization No. 6.02.671-1) in June 2013. The species was collected in February 2013, lot code MARPP01/0213 and validity period from 02.04.2013 to 02.04.2016.

\subsection{Extraction and isolation}

The bark and wood powder of $P$. olacoides (500 g) was extracted with a solvent gradient of increasing polarity under sonication using $n$-hexane, ethyl acetate and methanol. After extraction and removal of the solvent under vacuum in a rotatory evaporator, a dark residue was obtained $(4.10 \mathrm{~g})$ from the methanol extract (ME). The ME fraction (2.6 g) was restructured in methanol and filtered using Fisherbrand nylon $0.2 \mu \mathrm{m}$ filter to obtain a particle-free extract. The extract was then chromatographed on lipophilic Sephadex LH-20 (25-100 $\mu \mathrm{m})$ and eluted with $\mathrm{MeOH}{ }^{9}$ resulting mainly in 12 fractions (MEF1-12). MEF8 (20 mg) was subsequently purified by preparative RP-HPLC [mobile phase: $\mathrm{H}_{2} \mathrm{O} / \mathrm{AcOH}$ (99:1) (solvent $A$ ) and $\mathrm{MeOH}$ (solvent $\mathrm{B}$ ) at a constant flow rate of 5 $\mathrm{mL} / \mathrm{min}$, using $65 \%$ solvent $B$ and $35 \%$ solvent $A$, detection at $340 \mathrm{~nm}$ ] resulting in substances 1 (1.0 mg), 2 (1.0 mg), and $\mathbf{3}$ (1.0 $\mathrm{mg})$.

\subsection{Identification}

The NMR spectra of compounds 1-3 were acquired with ${ }^{1} \mathrm{H}, \mathrm{COSY}, \mathrm{HSQC}$ and $\mathrm{HMBC}$ techniques. The MS data were obtained by LC/MS analysis of MEF8 using as mobile phase a gradient of $\mathrm{H}_{2} \mathrm{O} / \mathrm{AcOH}$ (99:1) (solvent $A)$ and $\mathrm{MeOH}$ (solvent $B$ ) starting with 35$80 \%$ of B (20 min), $80-92 \%$ of B (20-25 min), maintaining at $92 \%$ for $8 \mathrm{~min}$, with a flow rate of $1 \mathrm{~mL} / \mathrm{min}$. Data acquisition was 
accomplished with the Chromera ${ }^{\circledR}$ software version 3.4.1. Compounds were further analyzed by UV spectroscopy with the shift reagents $\mathrm{AlCl}_{3}$ and $\mathrm{AlCl}_{3} / \mathrm{HCl}^{10}$

3-O-methylquercetin (1): yellow oil; UV (MeOH): $\lambda_{\max }$ (log $\left.\varepsilon\right): 245,300,355 ;(\mathrm{MeOH}+$ $\left.\mathrm{AlCl}_{3}\right): \lambda_{\max }$ (log $\varepsilon$ ): 235, 265, 440; (MeOH + $\left.\mathrm{AlCl}_{3} / \mathrm{HCl}\right): \lambda_{\max }(\log \varepsilon): 230,265,405 ;{ }^{1} \mathrm{H}$ NMR $\left(500.00 \mathrm{MHz}, \mathrm{CD}_{3} \mathrm{OD}\right): \delta(\mathrm{ppm})=6.21(\mathrm{~s}, 1 \mathrm{H}$, $\mathrm{H}-6), 6.40(\mathrm{~s}, 1 \mathrm{H}, \mathrm{H}-8), 7.65$ (s, 1H, H-2'), 6.93 $\left(\mathrm{d}, J=8.3 \mathrm{~Hz}, 1 \mathrm{H}, \mathrm{H}-8^{\prime}\right), 7.56(\mathrm{~d}, J=8.3 \mathrm{~Hz}, 1 \mathrm{H}$, H-6'), $3.81\left(\mathrm{~s}, 3 \mathrm{H}, \mathrm{OCH}_{3}-3\right)$; MS: $m / z 317$ $[\mathrm{M}+\mathrm{H}]^{+}$.

3,4'-O-dimethylquercetin (2): yellow oil; UV (MeOH): $\lambda_{\max }(\log \varepsilon): 255,295,355$; $\left(\mathrm{MeOH}+\mathrm{AlCl}_{3}\right): \lambda_{\max }(\log \varepsilon): 235,355,415$; $\left(\mathrm{MeOH}+\mathrm{AlCl}_{3} / \mathrm{HCl}\right): \lambda_{\max }(\log \varepsilon): 225,270$, $405 ;{ }^{1} \mathrm{H}$ NMR $\left(500.00 \mathrm{MHz}, \mathrm{CD}_{3} \mathrm{OD}\right): \delta(\mathrm{ppm})=$ $6.23(\mathrm{~d}, J=2.1 \mathrm{~Hz}, 1 \mathrm{H}, \mathrm{H}-6), 6.44(\mathrm{~m}, 1 \mathrm{H}, \mathrm{H}-8)$, $7.75\left(\mathrm{~d}, J=2.1 \mathrm{~Hz}, 1 \mathrm{H}, \mathrm{H}-2^{\prime}\right), 6.98(\mathrm{~d}, J=8.5$ $\mathrm{Hz}, 1 \mathrm{H}, \mathrm{H}-5^{\prime}$ ) e 7.67 (dd, $J=2.1,8.5 \mathrm{~Hz}, 1 \mathrm{H}, \mathrm{H}-$ $\left.6^{\prime}\right), 3.83\left(\mathrm{~s}, 3 \mathrm{H}, \mathrm{OCH}_{3}-3\right), 3.97(\mathrm{~s}, 3 \mathrm{H}, \mathrm{OCH} 3-$ $\left.4^{\prime}\right) ;{ }^{13} \mathrm{C}$ NMR (125.0 MHz, $\left.\mathrm{CD}_{3} \mathrm{OD}\right): \delta(\mathrm{ppm})=$ $56.4\left(\mathrm{CH}_{3}, \mathrm{OMe}-4^{\prime}\right), 60.4\left(\mathrm{CH}_{3}, \mathrm{OCH}_{3}-3\right), 94.7$ $(\mathrm{CH}, \mathrm{C}-8), 99.7(\mathrm{CH}, \mathrm{C}-6), 112.8\left(\mathrm{CH}, \mathrm{C}-2^{\prime}\right)$, $116.3\left(\mathrm{CH}, \mathrm{C}-5^{\prime}\right), 138.2\left(\mathrm{OCH}_{3}-3\right), 147.6\left(\mathrm{OCH}_{3}-\right.$ $\left.4^{\prime}\right)$; MS: $m / z 331[\mathrm{M}+\mathrm{H}]^{+}$.

3,7-O-dimethylquercetin (3): yellow oil; UV (MeOH): $\lambda_{\max }(\log \varepsilon): 240,300,370$; $\left(\mathrm{MeOH}+\mathrm{AlCl}_{3}\right): \lambda_{\max }(\log \varepsilon): 235,440 ;(\mathrm{MeOH}$ $\left.+\mathrm{AlCl}_{3} / \mathrm{HCl}\right): \lambda_{\max }(\log \varepsilon): 235,355,410 ;{ }^{1} \mathrm{H}$ NMR $\left(500.00 \mathrm{MHz}, \mathrm{CD}_{3} \mathrm{OD}\right): \delta(\mathrm{ppm})=8.6$ (brs, OH-5), 6.35 (d, J = 2.2, 1H, H-6), 6.61 (d, $J=2.2,1 \mathrm{H}, \mathrm{H}-8), 7.65\left(\mathrm{~d}, J=2.2,1 \mathrm{H}, \mathrm{H}-2^{\prime}\right)$, 4.83 (brs, OH- 3'-4'), 6.91 (d, $J=8.5 \mathrm{H}, \mathrm{H}-5^{\prime}$ ), $7.56\left(\mathrm{dd}, J=2.2,8.5 \mathrm{H}, \mathrm{H}-6^{\prime}\right), 3.80(\mathrm{~s}, 3 \mathrm{H}$, $\left.\mathrm{OCH}_{3}-3\right), 3.89\left(\mathrm{~s}, 3 \mathrm{H}, \mathrm{OCH}_{3}-7\right) ;{ }^{13} \mathrm{C} \mathrm{NMR} \mathrm{(125.0}$ $\left.\mathrm{MHz}, \mathrm{CD}_{3} \mathrm{OD}\right): \delta(\mathrm{ppm})=56.2\left(\mathrm{CH}_{3}, \mathrm{OCH}_{3}-7\right)$, $60.2\left(\mathrm{CH}_{3}, \mathrm{OCH}_{3}-3\right), 92.7(\mathrm{CH}, \mathrm{C}-8), 98.6(\mathrm{CH}$, C-6), 105.3 (C, C-10), 116.1 (CH, C-5'), 116.2 $\left(\mathrm{CH}, \mathrm{C}-2^{\prime}\right), 121.0\left(\mathrm{C}, \mathrm{C}-1^{\prime}\right), 122.1\left(\mathrm{CH}, \mathrm{C}-6^{\prime}\right)$, $138.3\left(\mathrm{OCH}_{3}-3\right), 145.1\left(\mathrm{C}, \mathrm{OH}-3^{\prime}\right), 148.7$ (C, OH-4'), 156.9 (C, C-2), 161.4 (C, OH-5), 165.9 $\left(\mathrm{OCH}_{3}-7\right) ; \mathrm{MS}: \mathrm{m} / \mathrm{z} 331[\mathrm{M}+\mathrm{H}]^{+}$.

\subsection{Cytotoxic activity assay}

Crude methanol extract (ME) was evaluated for in vitro cytotoxicity against three human tumor cell lines, melanoma (SKMel 28), gastric ascites (AGP-01) and breast carcinoma (MCF-7), and one non-tumor cell line, fetal lung fibroblast (MRC5), using the Alamar Blue (AB) assay. ${ }^{11}$ Doxorubicin was used as positive control. The concentration of samples resulting in 50\% growth inhibition $\left(I_{50}\right)$ was calculated for each cell line in GraphPad Prism ${ }^{\circledR}$ 5.0.

\section{Results and discussion}

Three flavonoids, 3-O-methylquercetin (1), 3,4'-O-dimethylquercetin (2) and 3,7-Odimethylquercetin (3) were isolated from the methanolic extract of the bark and wood of $P$. olacoides (Fig. 1) for the first time. The structures of compounds are supported by 1D $\left({ }^{1} \mathrm{H}\right.$ and $\left.{ }^{13} \mathrm{C}\right)$ and 2D (COSY, HSQC and HMBC) NMR experiments, UV and LC-ESI-MS analysis, and are in agreement with those reported in the literature. ${ }^{12}$ UV shifts data confirmed the position of the free hydroxyl groups. These confirmations were possible once the use of the shift reagents $\mathrm{AlCl}_{3}$ and $\mathrm{AlCl}_{3} / \mathrm{HCl}$ permits differentiation of the formation of acid-stable complexes between hydroxyls and neighboring ketones, and acidlabile complexes with orto-dihydroxyl groups. Thus, the bathochromic shift caused by $\mathrm{AlCl}_{3} / \mathrm{HCl}$ on band 1 of the spectra of 1-3 is characteristic of a free hydroxyl group in carbon atom C-5, and the absence of oxygen atom at carbon C-6 along with the bathochromic shift caused by $\mathrm{AlCl}_{3}$ on band 1 of the spectra of $\mathbf{1}$ and $\mathbf{3}$, is characteristic of orto-dihydroxyl groups on B-ring. ${ }^{10}$

Crude methanol extract was evaluated in vitro for its cytotoxic activity against gastric ascites (AGP-01), breast (MCF-7) and melanoma (SK-Mel-28) cancer cells. The crude extract presented a moderate cytotoxic effect against MCF-7, with $\mathrm{IC}_{50}$ of 45.16 $\mu \mathrm{g} / \mathrm{mL}$, when compared with doxorubicin (positive control). In addition, the extract did 
not display cytotoxicity against MRC-5 (nontumor human fibroblast cells).

Although we have not studied the cytotoxic activity of the isolated flavonoids, literature reports that these quercetin derivatives exhibit a variety of biological activities, including antiproliferative and antioxidant properties. ${ }^{13}$ For instance, Talib and co-workers ${ }^{13 b}$ described the antiproliferative activity of 1 against MCF-7 cells with an $\mathrm{IC}_{50}$ value of $11.23 \mu \mathrm{g} / \mathrm{mL}$. Therefore, the compounds described in this paper may be important for the cytotoxic activity against MCF-7 cancer cells.<smiles>COc1c(-c2ccc(O)c(O)c2)oc2cc(O)cc(O)c2c1=O</smiles><smiles>COc1ccc(-c2oc3cc(O)cc(O)c3c(=O)c2OC)cc1O</smiles>

Figure 1. Structures of flavonoids 1-3 isolated from the methanolic extract of wood and bark of Ptychopetalum olacoides Benth

\section{Conclusion}

This is the first report on isolation of flavonoids and cytotoxic activity for the genus Ptychopetalum. Bioguided assays should be further performed in order to confirm that these flavonoids are the main active compounds involved in the cytotoxic activity.

\section{Acknowledgements}

The authors gratefully thank the financial support of FAPERJ for this study, the research stipends from CAPES to KDBD and, from CNPq, to ALM, ALV, RCM, RAE and TRAV.

\section{References}

${ }^{1}$ Silva, R. A. D., Plantas medicinais Brasileiras: estudo botânico e pharmacognóstico Muirapuama. Revista Brasileira de Medicina e Pharmacia 1925, 1, 37.
${ }^{2}$ Rossi, L., Olacaceae. Em Lista de espécies da Flora do Brasil. Jardim Botânico do Rio de Janeiro, Instituto de Pesquisas Jardim Botânico do Rio de Janeiro: Rio de Janeiro, Brazil, 2014; Vol. 2, pp 1339. [Link]

${ }^{3}$ Siqueira, I. R.; Fochesatto, C. n.; Silva, A. L.; Nunes, D. S.; Battastini, A. M.; Netto, C. A.; Elisabetsky, E., Ptychopetalum olacoides, a traditional Amazonian "nerve tonic", possesses anticholinesterase activity. Pharmacology Biochemistry and Behavior 2003, 75, 645. [CrossRef] [PubMed]

${ }^{4}$ Antunes, E.; Gordo, W. M.; Oliveira, J. F.; Teixeira, C. E.; Hyslop, S.; De Nucci, G., The relaxation of isolated rabbit corpus cavernosum by the herbal medicine Catuama ${ }^{\circledR}$ and its constituents. Phytotherapy Research 2001, 15, 416. [CrossRef] [PubMed]

${ }^{5}$ Montrucchio, D. P.; Migeuel, O. G.; Miguel, M. D.; Monache, F. D.; Carvalho, J. L. S., Chemical compounds and antimicrobial activity of Ptychopetalum olacoides Bentham. Visão Acadêmica 2005, 6, 48. [CrossRef]

${ }^{6}$ a) Tang, W.; Hioki, H.; Harada, K.; Kubo, M.; Fukuyama, Y., Clerodane diterpenoids with NGF-potentiating activity from Ptychopetalum olacoides. Journal of Natural Products 2008, 71, 1760; [CrossRef] 
[PubMed] b) Tang, W.; Kubo, M.; Harada, K.; Hioki, H.; Fukuyama, Y., Novel NGFpotentiating diterpenoids from a Brazilian medicinal plant, Ptychopetalum olacoides. Bioorganic \& Medicinal Chemistry Letters 2009, 19, 882; [CrossRef] [PubMed] c) Tang, W.; Harada, K.; Kubo, M.; Hioki, H.; Fukuyama , Y., Eight new clerodane diterpenoids from the bark of Ptychopetalum olacoides. Natural Product Communications 2011, 6, 327. [PubMed]

${ }^{7}$ Colombo, R.; Batista, A. N. d. L.; Bomfim, G. C. C.; Burgos, R. C. R.; Cavalheiro, A. J.; Bolzani, V. S.; Silva, D. H. S.; Reimberg, M. C. H., Validated high-performance liquid chromatographic method for the standardisation of Ptychopetalum olacoides Benth., Olacaceae, commercial extracts. Brazilian Journal of Pharmacognosy 2010, 20, 781. [CrossRef]

${ }^{8}$ Rolim, A.; Maciel, C. P. M.; Kaneko, T. M.; Consiglieri, V. O.; Salgado-Santos, I. M. N.; Velasco, M. V. R., Validation assay for total flavonoids, as rutin equivalents, from Trichilia catigua Adr. Juss (Meliaceae) and Ptychopetalum olacoides Bentham (Olacaceae) commercial extract. Journal of AOAC International 2005, 88, 1015. [PubMed]

${ }^{9}$ Picerno, P.; Mencherini, T.; Rastrelli, L.; Piccinelli, A.; Aquino, R., Isoprenoid glycosides from Liriosma ovata. Journal of Natural Products 2008, 71, 265. [CrossRef] [PubMed]

${ }^{10}$ Markham, U. R., Techniques of flavonoid identification. Em Biol. Plantarum, Challice, J., Ed. Academic Press: London, New York, 1982; Vol. 26, pp 36. [CrossRef]

${ }^{11}$ Nakayama, G. R.; Caton, M. C.; Nova, M. P.; Parandoosh, Z., Assessment of the Alamar Blue assay for cellular growth and viability in vitro. Journal of Immunological Methods 1997, 204 (2), 205. [CrossRef] [PubMed]

${ }^{12}$ a) Kwon, Y. S.; Kim, C. M., Antioxidant constituents from the stem of Sorghum bicolor. Archives of Pharmacal Research
2003, 26, 535; [CrossRef] [PubMed] b) Costa, F. J.; Bandeira, P. N.; Albuquerque, M. R. J. R.; Pessoa, O. D. L.; Silveira, E. R.; Braz-Filho, R., Constituintes químicos de Vernonia chalybaea mart. Química Nova 2008, 31, 1691; [CrossRef] c) Rashed, K.; Sahuc, M.-E.; Deloison, G.; Calland, N.; Brodin, P.; Rouillé, Y.; Séron, K., Potent antiviral activity of Solanum rantonnetii and the isolated compounds against hepatitis $C$ virus in vitro. Journal of Functional Foods 2014, 11, 185. [CrossRef]

${ }^{13}$ a) Torres, F.; Quintana, J.; Estévez, F., 5,7,3'-trihydroxy-3,4'-dimethoxyflavone-

induced cell death in human Leukemia cells is dependent on caspases and activates the MAPK pathway. Molecular Carcinogenesis 2010, 49, 464; [CrossRef] [PubMed] b) Talib, W. H.; Zarga, M. H. A.; Mahasneh, A. M., Antiproliferative, antimicrobial and apoptosis inducing effects of compounds isolated from Inula viscosa. Molecules 2012, 17, 3291; [CrossRef] [PubMed] c) Santos, K. P.; Motta, L. B.; Santos, D. Y. A. C.; Salatino, M. L. F.; Salatino, A.; Ferreira, M. J. P.; Lago, J. H. G.; Ruiz, A. L. T. G.; Carvalho, J. E.; Furlan, C. M., Antiproliferative activity of flavonoids from Croton sphaerogynus Baill. (Euphorbiaceae). BioMed Research International 2015, 2015, 7; [CrossRef] [PubMed] d) Shi, Z.-H.; Li, N.-G.; Tang, Y.-P.; Shi, Q.-P.; Zhang, W.; Zhang, P.-X.; Dong, Z.-X.; Li, W.; Zhang, X.; Fu, H.-A.; Duan, J.-A., Synthesis, biological evaluation and SAR analysis of $O$-alkylated analogs of quercetin for anticancer. Bioorganic \& Medicinal Chemistry Letters 2014, 24, 4424; [CrossRef] [PubMed] e) Vargas, F. d. S.; Almeida, P. D. O.; Boleti, A. P. A.; Pereira, M. M.; Souza, T. P.; Vasconcellos, M. C.; Nunez, C. V.; Pohlit, A. M.; Lima, E. S., Antioxidant activity and peroxidase inhibition of Amazonian plants extracts traditionally used as antiinflammatory. BMC Complementary and Alternative Medicine 2016, 16, 83. [CrossRef] [PubMed] 